\title{
A world threatened by populism. Remarks on security in modern times
}

\author{
Tomasz Czura ${ }^{1}$, \\ ${ }^{1}$ Wyższa Szkoła Biznesu - NLU w Nowym Sączu \\ ul. Zielona 27, Nowy Sacz - Poland
}

\begin{abstract}
The article is an attempt to answer the question about the importance of populism in contemporary reflection on security in its broadest sense. The author of these analyses tries to find the reasons for the growing populist trend, which occurs not only in the political dimension, but permeates almost all social life. In the context of such a goal, the connection between populism and ideology and nihilism is shown. As a consequence of the methodological principles adopted, two types of populism were distinguished: ideological and nihilistic. Ideological populism is characterized by a high degree of indeterminacy and makes farreaching simplifications and generalisations. In this perspective, the enemies of the people are both newcomers, strangers, immigrants, as well as sexual, ethnic and other minorities.Nihilist populism is more depressing. It is based on the recognition of fragmentation as a basic indicator of values. The individual, detached from the wider background, is in a way the programme of populism understood in this way. A simple consequence of nihilistic populism is the uprooting of the individual, which results in consumerist attitudes. In this sense, one can say that nihilistic populism is aimed at justifying consumptionism, i.e. it provides an ideological foundation for the carefree use of material goods.
\end{abstract}

Index Terms - security, populism, crisis, cultural security.

\section{INTRODUCTION}

I guess no one doubts that we're living in the time of the breakthrough. The last period of global transformation took place in the nineteenth and twentieth century, when the development of railways aroused general anxiety combined with fascination. German psychiatrist Michael SchulteMarkwort writes about contemporary technological development and the time of transformation in the following way: "It is certain that childhood - but also the lives of us adults - are constantly changing, sometimes even radically, in the face of the next industrial revolution that is on its doorstep (...) We gladly forget that in 1835 there were scientific studies on the fact that people are not adapted to speeds in excess of $30 \mathrm{~km} / \mathrm{h}$. The dangers of railways were pointed out in this way". (ShulteMarkwort 2019, p. 276).

ASEJ - Scientific Journal of Bielsko-Biala School of Finance and Law

Volume 24, No 1 (2020), 4 pages

DOI: $10.5604 / 01.3001 .0014 .1348$

Received: 30 January 2020; Accepted: 22 February 2020
Today, many people believe that progress can give man the happiness he desires. However, the image full of hope is disturbed by the "prophets" who are boasting the annihilation of humanity. Many people ask themselves, where is the truth? Does success lead us to perdition? Can man save himself and protect himself from evil? Is the annihilation of humanity foregone?

These questions seem to be unanswered. For each of us has met in our lives representatives of both the blind faith in infinite development and those who are boasting the end of humanity in the near future. So how to find balance? What is the main problem of our times, and what is the finger-sucking horror film used to keep people in check?

On the one hand, we seem to have nothing to fear that things are going in the right direction. But sometimes, somewhere in the depths, we feel that the world is running towards extinction. The aim of these analyses will be to show the main problem that makes the modern world drift in an unpredictable direction. This problem is populism, which has many different varieties that cannot be reduced to a simple definition. Before we ask about populism, therefore, we should understand what ideology and nihilism are, which are the predictions of the populist revolution in the second decade of the 21 st century.

\section{IDEOLOGY}

Contemporary culture with its characteristic pluralism is a space for dialogue not only with faith, but also with different world views. It seems to be rich in openness to diversity, which creates the conditions for an exchange of views, but also promotes the verification of truths that are often too hastily accepted. In the context of this culture, philosophical thought appears as one of many proposals addressed to man. The recognition and appreciation of distinctiveness promotes the development of individuality and increases the chances of emerging from the shadows of those who, for various reasons, have so far remained on the margins of social life. The emphasis

Regular research paper: Published 30 April 2020

Corresponding author's e-mail: tomek.cz1@vp.pl

Copyright (C) 2018 This is an open access article distributed under the Creative Commons Attribution CC-BY-NC 4.0 License. 
on diversity in contemporary culture is intended to give dignity to what was often overlooked. However, such an image of culture, although positive, does not eliminate the threats to which contemporary man is exposed. One of them is extreme individualism, losing a broader perspective and pushing man into loneliness. Lack of ability to create community, loss of passion for seeking truth and, as a result, lack of hope - these are the main problems faced by man. Hence, the question of what to do to preserve, on the one hand, the contemporary tendency to give dignity to the individual and, on the other hand, how not to lose the healthy relations that make up the community? In order to answer this question it is necessary to read carefully into contemporary philosophical thought in its historical dimension. Philosophy opens up a new perspective for man, which consists in maintaining a lively contact with man and his problems.

The concept of nihilism is connected with the nineteenthcentury crisis of European culture. Many philosophers, however, see nihilism as a historical problem, dating back to the philosophical beginnings. In a sense, already the sofists, skeptics, by negating the truth, the meaning of life, prepared the ground for contemporary nihilism. We are well aware today how important it was for the Protagoras to say words about man, who is the measure of all things: "Man is the measure of all things, existing, non-existent, non-existent." (Diogenes Laertios, 1984, p. 545). For the Greeks who professed their faith in the gods, it must have been a great shock. Hence the persecution of those philosophers who openly opposed the cult of the gods, who would be responsible for the fate of man. It was no accident that the works of Protagoras, who openly claimed that: "I cannot know about the gods, neither that they exist nor that they don't exist; for there are many obstacles to such knowledge that I will only mention the impossibility of sensory experience in this field and the shortness of human life." (Diogenes Laertios, 1984, p. 546).

Contemporary nihilism is a very ambiguous and difficult phenomenon to grasp. Jan Patočka pointed to the problem of post-war nihilism, which consists in resignation. In this perspective, nihilism would be a lack of interest in values and general cognitive apathy caused by war trauma (Patočka, 1993, p. 133). The Italian philosopher and theologian Bruno Forte writes: "Nihilism is not a rejection of values, a renunciation of something worth living for, but a more subtle process. It deprives the human being of the desire to commit himself to a higher reason [...] What makes the human being most sick today is the lack of "passion for the truth": this is the tragic face of post-modernity" (Forte, 2007, p. 28). The above quotation makes it possible to recognize in nihilism not only a certain moral problem, but also an existential problem, a certain state of man who loses hope and ultimately falls into the abyss of solitude (Forte 2007, p. 29). As a man who is by nature destined to build up a community, to meet others, in a state of isolation, of inner alienation, he begins to compensate for the suffering of solitude by turning to the world of things. It is this loneliness that leads man to extreme consumerism, a mad pursuit of possession. In this way the human world becomes more and more the world of things, the primacy of being is replaced by the primacy of possession. Given the natural need for closeness with which a person opens up to another person, the trick of turning to the world of things only deepens the feeling of loneliness.

According to the aforementioned Bruno Frote, it is not only nihilism that constitutes a serious threat to modern man. In his opinion, ideological thinking is still a current temptation. He writes: "The intoxication of the modern spirit consists precisely in the assumption of the absoluteness of reason, that it can overcome any ambiguity and absorb any diversity... The final manifestation of this intoxication is ideology" (Forte, 2007, p.29).

Although the two great ideologies of the twentieth century have already gone down in history, the temptation to think in an ideological way, i.e. according to ready-made schemes, is still valid. Ideological thinking is convenient because it somehow takes the responsibility away from the thinking person because it provides them with ready-made thought structures. A person who submits to ideology easily identifies himself or herself with the ideological line. It seems to him or her that he or she is thinking on his or her own, while he or she is taking other people's patterns. On the one hand, therefore, there is ideological thinking in which the individual dissolves completely and, on the other hand, extreme subjectivity, where individualism becomes the sole criterion for thinking and acting.

Both extreme forms of thinking threaten contemporary man and, as we will try to prove, cause further threats, the most serious of which is populism.

\section{IDEOLOGICAL POPULISM}

It is obvious that there is a convergence between the ideological position and populism. One can even risk the claim that populism is a form of ideology in which the abstract and only rightful will of the people comes to the fore, being the opposition of the elite. Abstractiveness and generality of populist expressions have this to do with the fact that it is impossible to verify. What would be the threat from elites like judges for example? The generality of the debate and the ubiquitous logical error pars pro toto (the logical error of taking a part of a thing as a whole) do not allow us to understand what really threatens the simple and honest, and thus almost "holy people"? All we know is that there are mysterious groups, forces present somewhere, which are at the service of other powers or countries that want to betray the ideals of a simple people. The mentioned mistake pars pro toto consists in the media picturing individual cases of pathological behaviour of elite representatives. These images are then generalized and shown as the norm in a given environment. In this way we see a judge, a doctor, or other representative of the elite who is committing a shameful act. Then he is presented as a typical representative of a given caste, which is the habitat of pathology.

In populist ideology, the problem is not only the elite, but also strangers, strangers, immigrants. The policy of populist parties promotes the interests of the indigenous inhabitants by 
taking advantage of the supposed danger that comes from outside and deprives people of a prosperous life in peace. Immigrants are seen as a general threat (Gomółka, Lublin 2018, p. 390). Hence, they are being fought by populist governments, which adhere to the principle that "Poland is for Poles only". The newcomers from other parts of the world are seen only as a threat. A foreign culture, religion, is shown as threatening the social order of the country. Especially if we are dealing with Muslim culture and religion (Gomółka 2018, p. 390-391).

It is worth noting that ideological populism breaks the historical continuity and always strives for revolution. What is past is weak and meaningless. Therefore, according to the populists, we should break with the old world order in the name of a better tomorrow. What is old is a continuation of pathologies and all abuses, which are continued and carried by the elite and influential groups of people who want to pursue foreign interests at the expense of the people.

\section{NIHILISTIC POPULISM}

Another threat to the modern social order is nihilistic populism. Nihilism itself was mentioned above. Currently, we would like to show what nihilistic populism is about. We will try to show the deep connection between such populism and the problem of uprooting a person from their living environment, which later translates into the way they function in the family environment, workand more broadly in society. We will show how a person uproots his or her proper relationships in the workplace and, looking for compensation, falls into everincreasing consumerism, which at the end turns out to be a rotten fruit of populism.

There is no need to convince anyone about the great problem of consumerism. Its direct result is, among other things, the enormous pollution of the planet. Many experts are of the opinion that if we do nothing about it, the problem will get even worse and may lead to a climate catastrophe. What is worrying is the fact of continuous growth of consumption also in Poland, which is presented by the following data of GUS (Raport: current consumer confidence indicator, gus.gov.pl):

The development of consumerist attitudes is led by nihilistic populism, which uproots man, causes a deep wound in his relations and pushes him to extreme existential situations, which consist in man closing himself in the shell of egoism. How does the proper relations that man should have with himself and with the outside world come to be disturbed? Where, outside the family, does man confirm his rootedness in social life? What constitutes the formation of proper relations to material goods and pay for work?

To answer these questions, we must enter into the problem of the dynamics of work.

The rootedness of an employee in the workplace is the basic problem of the modern world of work. The crack between the time spent at home and the time spent at work causes the human being to function in both places half - and unauthentically. A certain regularity can be introduced, namely the lack of rootedness at work also causes rooting at home. Of course this mechanism works the other way round and people rooted out in their home environment alienate themselves at work as well. The sign of such uprooting is consumerism, which in its essence is an attempt to compensate for the misery associated with a lack of rootedness.

We often meet people who have to play themselves at work in order to survive, which is a modern form of slavery. On top of this, there is the problem of bureaucratization and complicated computerization, which translates into the quality of time spent at work. Work ceases to be a form of employee's rooting, and the environment of co-workers and means of work turn against man. This leads to a form of being inauthentic and building relationships based on falsehood. The employee then takes up a kind of game in his work environment, trying to arouse the sympathy of his superiors at all costs. Then a superior-subordinate relationship is born, similar to the masterslave relationship, with the simultaneous paradox that the master begins to need flattery and thus becomes dependent on his subordinate.

The lack of rootedness also affects relations with household members and friends as well as with material goods. One of the main threats is consumerism, which is born out of an attempt to compensate for work full of misery and alienation. A worker who is alienated spends the money he has earned on pleasures in order to forget about his misery for a moment. In this way, uprooting gives rise to idolatry.

It is not, of course, a total negation of hedonistic culture, but rather its placement in the context of uprooting. A moderate hedonistic culture in a community of people rooted in the workplace and living environment does not present itself as harmful (Sapiński 2019, p.4) . On the contrary, the use of goods that give pleasure in a deeply rooted environment can be considered a manifestation of happiness on earth. In other words, management is the rooting of man in the workplace and in the living environment, while respecting the rights of the human conscience. Conscience allows a person to enjoy life without closing him or her in on values. Man's goal is not to be extremely hedonistic about happiness, but to be rooted in the environment of life and work and to introduce into these environments values that are important to him.

\section{CONCLUSIONS}

At least a few conclusions can be drawn from what has been said so far.

Firstly, populism is currently a very serious threat not only in the political sphere, but also and above all in the area of social life in the broad sense. The influence of populism on people's lives is not limited only to the political dimension, but it penetrates deeply into the mind and shapes attitudes full of mistrust and disorderly pursuit of possession.

Secondly, the division into ideological and nihilistic populism is of great importance because it allows for a proper assessment of this phenomenon. Ideological populism is an attempt to influence society using old methods that generalise and simplify reality. An important element of such populism is the creation of hostile forces that threaten the interests of the people. It is a movement hostile to elites, strangers, immigrants, 
religious and ethnic minorities. Nihilistic populism, in turn, leads to the fragmentation of reality and, as a result, isolation. The slogans of nihilistic populism are extremely selfish, they call for caring only for one's own, private good while breaking with the common good. Nihilistic populism deprives man of his roots, takes away his community abilities and leads him astray from consumerism.

Thirdly, both ideological and nihilistic populism arouse extremely unpleasant and strong emotions. A man overwhelmed by populist slogans carries within him not only resentment and hostility towards alleged enemies, but also aggression, loneliness, possessions, pain, bitterness and a sense of overstretching.

Fourth, populism very often leads to social revolutions. Hence the prophets of populism call for revolutionary changes, they break with the existing social order, create a new sociopolitical order. They promise a new era of prosperity and happiness. Despite the noisy announcements, they most often leave the ruins behind.

To sum up, it can be said that populism takes away man's ability to think critically and clearly, making reality a simplified ideology. This simplification is all the more dangerous because populism imitates the truth, imitating it in a very convincing way. That is why populism is so dangerous. There is another very important fact that makes populism spread very quickly and fall into the vulnerable ground. The point is that populism is cleverly and equally convincingly imitating democracy. The leading prophets of populism point out that their proposals are a perfect fulfilment of the will of the people. This is what the people want, and we, the true and only executors of the people's will, can ensure that the desires and dreams of ordinary people are fulfilled - this is what populists seem to think and say. Although the difference between populism and democracy is subtle and not everyone can see it, it is obvious. In a democracy, there are a number of legal regulations between the will of the people and its execution. If a "sovereign", as populists emphasize, has power and the last word belongs to it, then not every will of the people can be realized. There are many reasons for not agreeing to the people's will. The will of the people is not always in accordance with the constitution, national and international laws, various agreements and conventions, European Union law and the Declaration of Human Rights. In a democracy, the will of the majority is realized, but with respect for the law! In a system based on populist slogans, citizens are told that their will is sacred and that the lack of its realization is the result of the bad will of those in power, who most often appear as bribes and dishonest minions of foreign powers, influences and interests. The Popularists promise that their rule will be an ideal realization of the will of the people, without looking at anyone or anything. The difference between democracy and populism is far too little emphasized. Since populism is a caricature of democracy, a caricature more attractive than the original, it is therefore so dangerous and threatens us today with double force.

\section{REFERENCES:}

Diogenes Laertios. (1984). Żywoty i poglądy słynnych filozofów. Warszawa: Państwowe Wydawnictwo Naukowe.

Forte B. (2007). Istota chrześcijaństwa. Lublin: Wydawnictwo KUL.

Gomółka K. (2018). Współczesne partie polityczne w Polsce wobec problemu imigracji i imigrantów, w: Chałupczak H., Lesińska M., Pogorzała E., Browarek T. (red.).Polityka migracyjna w obliczu współczesnych wyzwań. Teoria i praktyka. (385-398). Lublin: Wydawnictwo Uniwersytetu Marii CurieSkłodowskiej.

Patočka J. (1993). Człowiek duchowy a intelektualista. Logos i Ethos, nr 1 s. 131-142.

Sapiński A. (2019). Intergenerational management in the group of people subjected to job reintegration as a form of maintaining social security potential in Poland. Knowledge and Performance Management, 3(1), 1-5. doi:10.21511/kpm.03(1).2019.01

Shulte-Markwort M. (2019). Zaburzenia u dzieci i młodzieży. Warszawa: Wydawnictwo Dobra Literatura.

Weil S. (1961). Zakorzenienie. Warszawa: Państwowe Wydawnictwo Naukowe. 